\title{
Synthesis of 4-methoxy-2-thiomorpholin-4-ylmethyl-1-phenol
}

\author{
Ana María Velázquez ${ }^{1}$, Luis Alberto Torres ${ }^{1}$, Raúl González ${ }^{1}$, Alvaro Valencia ${ }^{1}$, Sandra Díaz-Barriga ${ }^{1}$, Italo \\ Menconi $^{1}$, Luisa Martínez ${ }^{1}$, Alberto Ramírez ${ }^{1}$, Ignacio Martínez, Brígida Camacho ${ }^{1}$, Rafael López-Castañares ${ }^{2}$, \\ Enrique Angeles 1,*
}

1 Facultad de Estudios Superiores Cuautitlán, Universidad Nacional Autónoma de México, México

2 Facultad de Química de la UAEM, Universidad Autónoma del Estado de México

* Author to whom correspondence should be addressed. E-mail: angeles@servidor.unam.mx

Received: 19 January 2007 / Accepted: 24 February 2007 / Published: 23 August 2007

Keywords: 4-methoxyphenol, thiomorpholine, IR<smiles>COc1ccc(O)cc1</smiles>

1

\section{Formaldehyde \\ Thiomorpholine \\ IR irradiation}<smiles>COc1ccc(O)c(CN2CCSCC2)c1</smiles>

2

Infrared light activation as a non-conventional energy source has become an important method that can be used to carry out a wide range of reactions with short reaction times and high yields. Indeed, infrared light heating rapidly increases temperature in absence of the solvent and leads to a uniform energy transfer to the reactants of the chemical reaction. This method does not involve toxic materials, resulting in an economic process, which has clear advantages as an environmentally friendly, solvent-free alternative in organic synthesis. In our experience and, according to the reports in the literature, when the reaction mixtures were refluxed using ethanol as solvent in the absence of infrared light irradiation, the reaction times were in the range of 1-100 hours and the yields were lower.

4-methoxy-2-thiomorpholin-4-ylmethyl-1-phenol (2) was prepared from 4-methoxyphenol (1), 1 eq. of thiomorpholine and 2 eq. of formaldehyde. They were mixed in a round flask fitted with a condenser. The mixture was irradiated with infrared light using a medicinal infrared lamp ( 250 Watts) and the reaction was monitored by tlc, and after 8 minutes, the reaction was completed. The mixture was chromatographed on silica gel using solvent gradient hexane/ethyl acetate. Yield $76 \%$

Melting point: $102-104{ }^{\circ} \mathrm{C}$ (ethylacetate, uncorrected).

IR ( $\mathrm{n} \mathrm{cm}^{-1} ; \mathrm{CHCl}_{3}$ film): $3452(\mathrm{O}-\mathrm{H}), 3010\left(\mathrm{C}_{\mathrm{sp} 2-\mathrm{H}} \mathrm{Ar}\right), 2985\left(\mathrm{C}_{\mathrm{sp} 3}-\mathrm{H}\right)$.

${ }^{1} \mathrm{H}-\mathrm{NMR}\left(200 \mathrm{MHz} ; \mathrm{CDCl}_{3}\right.$; Me4Si, $\left.\delta_{\mathrm{H}}\right): 10.08(1 \mathrm{H}, \mathrm{s}, \mathrm{OH}), 7.74(2 \mathrm{H}, \mathrm{m}), 6.55(1 \mathrm{H}, \mathrm{m}), 3.73(3 \mathrm{H}, \mathrm{s}), 3.66\left(2 \mathrm{H}, \mathrm{s}, \mathrm{Ar}-\mathrm{CH}_{2}\right)$, $2.82\left(4 \mathrm{H}, \mathrm{m},-\mathrm{S}^{-\mathrm{CH}_{2}-}\right), 2.71\left(4 \mathrm{H}, \mathrm{m},-\mathrm{N}-\mathrm{CH}_{2}-\right)$.

${ }^{13} \mathrm{C}-\mathrm{NMR}\left(50 \mathrm{MHz} ; \mathrm{CDCl}_{3} ; \delta_{\mathrm{C}}\right): 152.5(\mathrm{C}), 151.2(\mathrm{C}), 122.52(\mathrm{C}), 116.4(\mathrm{CH}), 111.5(\mathrm{CH}), 113.6(\mathrm{CH}), 62.3\left(\mathrm{Ar}-\mathrm{CH}_{2}\right), 55.66$ (CH3), $54.36\left(-\mathrm{N}_{-} \mathrm{CH}_{2}-\right), 27.82\left(-\mathrm{S}^{\left.-\mathrm{CH}_{2}-\right)}\right.$.

FAB-MS m/z (rel\%) (M+1): 240(25\%), 215, 180, 154.

Elemental Analysis: Calculated for $\mathrm{C}_{12} \mathrm{H}_{17} \mathrm{O}_{2} \mathrm{NS}$ (239): C $60.22 \%$, H $7.16 \%$, N $5.85 \%$, O $13.37 \%$, S $13.40 \%$, found : C $60.49 \%$, H $7.54 \%$, N $5.49 \%$, O $13.05 \%$, S $13.22 \%$.

\section{Acknowledgements}

The authors wish to acknowledge to PAPIIT/UNAM Projects No IN213606 and IN207705 and ALPHARMA SA de CV, by partially support this work. We would like to thank C.Barajas, F.Sotres, P.García, D.Jiménez from FESC-UNAM and Rosa I.del Villar M., Oscar Yañez and Georgina Duarte from USAI-UNAM for their skillful technical assistance and DGSCA-UNAM for their support. As a part of Project Cátedra Química Medicinal of FESC-UNAM.

\section{References}


1. Velázquez, A.Ma.; Torres, L.A.; Díaz, G.; Ramírez, A.; Hernández, R.; Santillán, H.; Martínez, L.; Martínez, I.; Díaz-Barriga, S.; Abrego, V.; Balboa, M.A.; Camacho, B.; López-Castañares, R.; Dueñas-González, A.; Cabrera, G.; Angeles, E. ARKIVOC 2006, 2, 150-161.

2. Biava, M.; Fioravanti, R.; Porretta, G.C.; Deidda, D.; Maullu, C.; Pompei, M. Biorg. \& Med. Chem. Lett. 1999, 9 , 2083-2985.

3. Teipel, S.; Griesar, K.; Haase, W.; Krebs, B. Inorganic Chemistry 1994, 33, 456-464.

4. Hodgkin, J.H. Aust. J. Chem. 1984, 37, 2371-2378.

(C) 2007 by MDPI (http://www.mdpi.org/). Reproduction is permitted for noncommercial purposes. 